\title{
First survey of the ants (Hymenoptera, Formicidae) of Piauí: filling a major knowledge gap about ant diversity in Brazil
}

\author{
Tainara Thais Jory ${ }^{1,2}$ \& Rodrigo Machado Feitosa ${ }^{1,3}$ \\ 1 Universidade Federal do Paraná (UFPR), Departamento de Zoologia (DZO0), Laboratório de Sistemática e Biologia de Formigas (LSBF). \\ Curitiba, PR, Brasil. \\ 2 ORCID: http://orcid.org/0000-0003-4302-7396. E-mail: jorytainara@gmail.com \\ 3 ORCID: http://orcid.org/0000-0001-9042-0129. E-mail: rsmfeitosa@gmail.com (correspondent author)
}

\begin{abstract}
Piauí, a Brazilian Northeast state, has been considered one of the most important regions for the presence of new taxa in ants globally, especially considering the ecosystems' diversity formed by the transition of the three biomes in the state, the Cerrado, Caatinga and the Atlantic Forest. Despite the recent increase in studies of ant diversity in the Neotropical region, Piauí still represents a major knowledge gap regarding its ant fauna. Therefore, this study aimed to increase the knowledge about the ant fauna of the state by generating a list of species with data obtained from the literature, online repositories and collection expeditions to the Serra da Capivara and Serra das Confusões National Parks. A total of 152 species in 52 genera and nine subfamilies were registered from 24 localities in Piauí. Fifty-eight out the 152 species recorded represent new records for the state, eight are new records for the Brazilian Northeast Region, and one consists of a new record for the country. Eleven species are here recognized as new for science. Considering the field expeditions carried out here, this work represents the first standardized study for the ant fauna of Piauí. The species list presented considerably exceeds the current number of species registered for the state so far. From the present 48 records, the number of species for Piaui raises to more than 150 with a tendency to increase with the accomplishment of future field endeavors and advances in the study of the local ants.
\end{abstract}

Key-Words. Cerrado; Caatinga; Atlantic Forest; Taxonomy; Conservation.

\section{INTRODUCTION}

Ants are eusocial insects grouped into a single family (Formicidae), which in turn is classified into 17 subfamilies and 334 genera (Bolton, 2019). Ants occur in great diversity and abundance in most ecosystems (Choe, 2012). In view of this, ants are extremely important ecologically and are key participants in many ecosystem processes (Lamanceau \& Blouin, 2018). In addition, these insects are also good indicators of environmental conservation status, since they are very sensitive to environmental stress (Silvestre et al., 2003; Ribas et al., 2012).

In the Brazilian Northeast, anthropic action has led to a deterioration of natural areas and drastic changes in the relief and other characteristics of the soil surface. The state of Piauí, located in this region, has been suffering human disturbances since the 1960s, when tax incentives for agricultural projects were implemented (Lacombe, 1969; Aguiar \& Monteiro, 2005). The key location of this state in a transition zone among three Brazilian biomes, the Cerrado, the Caatinga and the Atlantic
Forest, makes it a priority for the study of diversity. Despite recent advances, which translate into a 33\% reduction in deforestation of the state's Cerrado areas, Piauí remains a leader in the deforestation of that biome (MMA, 2018). Also, since it is one of the last agricultural frontiers in the Cerrado, the southern region of the state is under intense threat (Machado et al., 2004).

The ant fauna of Piauí has remained relatively unstudied compared to other Brazilian states (Camargo, 2011; Prado et al., 2019). One of the few studies involving the state's ant fauna shows that deforestation and loss of diversity by monocultures are very high. In the same study, the anthropic impact on the balance of local ecosystems was highlighted, together with the need for accurate surveys of the local diversity in order to develop more efficient conservation policies, and to promote the documentation of species that are present there before they go locally extinct (Fontes \& Almeida Filho, 2002).

Considering the growing need for inventories to fill knowledge gaps about the diversity of places that need to be given conservation prior- 
ity, regional species lists are an important tool (Castro et al., 2018; Demétrio et al., 2017; Vicente et al., 2018). The primary data generated by the inventory of animal and plant species are very important in decision-making regarding environmental conservation management. Similarly, as predominant and diverse organisms in any terrestrial environment, sampling the local ant fauna is essential. This is especially true when we consider the poorly explored regions of the state of Piauí, which are, on average, suffering more from deforestation than their surrounding areas and therefore deserve special attention regarding conservation and investment in scientific research. In fact, Brazil probably has a widely underestimated number of species and Piauí is where new genera are most likely to be found (Guénard et al., 2012). In this context, the objective of the present study is to increase the knowledge about the ant fauna of the state of Piauí by compiling records from literature, online repositories and field expeditions in two of the state's main National Parks.

\section{MATERIAL AND METHODS}

Species records were gathered from a comprehensive independent literature review and consultation of the online repository Antmaps.org. Each species listed here is validated by at least one published reference or data source and the validity of names has been verified in the Antcat.org platform (Bolton, 2019). To confirm the occurrences (Table 1) and to prepare the map (Fig. 1), the geographical coordinates, when not available in the respective reference, were georeferenced based on the Google Earth platform.

Table 1. Collecting locations and municipalities with ant records for the state of Piauí, Brazil, according the specific reference list below.

\begin{tabular}{|c|c|c|}
\hline Locality & Coordinates & Source \\
\hline Altos & $05^{\circ} 02^{\prime} 23^{\prime \prime} S 42^{\circ} 27^{\prime} 29^{\prime \prime} \mathrm{W}$ & 14 \\
\hline Bom Jesus & $09^{\circ} 11^{\prime} 29^{\prime \prime} \mathrm{S} 44^{\circ} 50^{\prime} 33^{\prime \prime} \mathrm{W}$ & 7 \\
\hline Buriti dos Lopes & $03^{\circ} 10^{\prime} 30^{\prime \prime} \mathrm{S} 41^{\circ} 52^{\prime} 01^{\prime \prime} \mathrm{W}$ & 10 \\
\hline Canto do Buriti & $08^{\circ} 06^{\prime} 36^{\prime \prime} \mathrm{S} 42^{\circ} 56^{\prime} 40^{\prime \prime} \mathrm{W}$ & $9 ; 17 ; 22$ \\
\hline Corrente & $10^{\circ} 26^{\prime} 30^{\prime \prime} S 45^{\circ} 09^{\prime} 52^{\prime \prime} \mathrm{W}$ & $4 ; 9 ; 10 ; 17$ \\
\hline Corrente 2 & $10^{\circ} 26^{\prime} 00^{\prime \prime} \mathrm{S} 45^{\circ} 09^{\prime} 00^{\prime \prime} \mathrm{W}$ & 1 \\
\hline Estação Ecológica Uruçuí-Uma, Bom Jesus & $08^{\circ} 51^{\prime} 50^{\prime \prime} \mathrm{S} 45^{\circ} 12^{\prime} 00^{\prime \prime} \mathrm{W}$ & 10 \\
\hline Floriano & $06^{\circ} 46^{\prime} 01^{\prime \prime} \mathrm{S} 43^{\circ} 01^{\prime} 21^{\prime \prime} \mathrm{W}$ & $10 ; 17$ \\
\hline Floriano 2 & $06^{\circ} 44^{\prime} 37^{\prime \prime} \mathrm{S} 43^{\circ} 02^{\prime} 49^{\prime \prime} \mathrm{W}$ & 23 \\
\hline Jacobina do Piauí & $08^{\circ} 00^{\prime} 00^{\prime \prime} \mathrm{S} 41^{\circ} 25^{\prime} 00^{\prime \prime} \mathrm{W}$ & 2 \\
\hline Marvão & $05^{\circ} 19^{\prime} 59^{\prime \prime} \mathrm{S} 41^{\circ} 32^{\prime} 60^{\prime \prime} \mathrm{W}$ & 14 \\
\hline Matias Olimpio & $03^{\circ} 42^{\prime} 58^{\prime \prime} \mathrm{S} 42^{\circ} 33^{\prime} 18^{\prime \prime} \mathrm{W}$ & 10 \\
\hline Oeiras & $07^{\circ} 01^{\prime} 31^{\prime \prime} \mathrm{S} 42^{\circ} 07^{\prime} 52^{\prime \prime} \mathrm{W}$ & $4 ; 9 ; 22$ \\
\hline 0eiras 2 & $07^{\circ} 00^{\prime} 59^{\prime \prime} S 42^{\circ} 07^{\prime} 16^{\prime \prime} \mathrm{W}$ & 3 \\
\hline Parnaíba & $02^{\circ} 54^{\prime} 19^{\prime \prime} S 41^{\circ} 46^{\prime} 24^{\prime \prime} \mathrm{W}$ & 14 \\
\hline Piauí - uncertain locality & - & $5 ; 6 ; 8 ; 16 ; 21$ \\
\hline Rio Uruçuí Preto & $07^{\circ} 19^{\prime} 00^{\prime \prime} S 44^{\circ} 37^{\prime} 00^{\prime \prime} \mathrm{W}$ & $\begin{array}{c}3 ; 10 ; 13 ; 15 ; 17 \\
19 ; 20\end{array}$ \\
\hline São Raimundo Nonato & $08^{\circ} 38^{\prime} 23^{\prime \prime} \mathrm{S} 42^{\circ} 46^{\prime} 32^{\prime \prime} \mathrm{W}$ & 23 \\
\hline Serra da Capivara, Coronel José Dias & $08^{\circ} 41^{\prime} 42^{\prime \prime} S 42^{\circ} 35^{\prime} 10^{\prime \prime} \mathrm{W}$ & 11 \\
\hline Serra das Confusões, Caracol & $09^{\circ} 13^{\prime} 22^{\prime \prime} \mathrm{S} 43^{\circ} 29^{\prime} 23^{\prime \prime} \mathrm{W}$ & 12 \\
\hline Sete Cidades & $04^{\circ} 05^{\prime} 59^{\prime \prime} \mathrm{S} 41^{\circ} 42^{\prime} 50^{\prime \prime} \mathrm{W}$ & 18 \\
\hline Teresina & $05^{\circ} 05^{\prime} 31^{\prime \prime} \mathrm{S} 42^{\circ} 48^{\prime} 13^{\prime \prime} \mathrm{W}$ & 14 \\
\hline Timon (Maranhão) & $05^{\circ} 04^{\prime} 59^{\prime \prime} \mathrm{S} 42^{\circ} 49^{\prime} 00^{\prime \prime} \mathrm{W}$ & 3 \\
\hline Uruçuí & $07^{\circ} 20^{\prime} 35^{\prime \prime} \mathrm{S} 44^{\circ} 37^{\prime} 00^{\prime \prime} \mathrm{W}$ & 3 \\
\hline
\end{tabular}

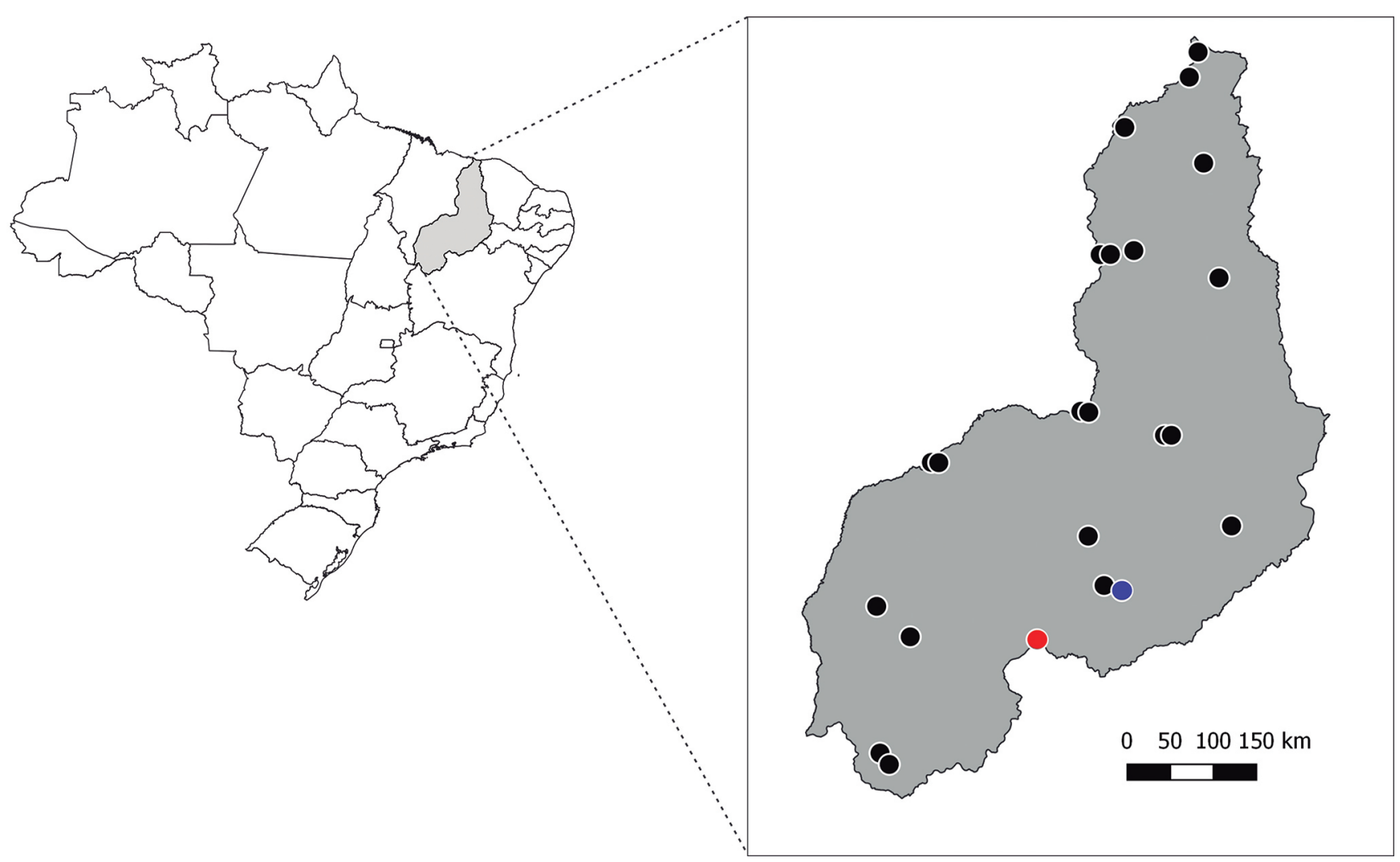

Figure 1. Areas with ant records in the state of Piauí, Brazil, based on literature review (black circles) and collecting expeditions of the present study to the Serra das Confusões (red circle) and Serra da Capivara (blue circle) National Parks. 
In addition to the bibliographic survey, two collecting expeditions were made to the Serra da Capivara and Serra das Confusões National Parks. In both parks, ants were collected with three distinct techniques: manual capture, pitfall traps in the soil and vegetation, and Winkler leaf-litter extractors.

Parque Nacional da Serra das Confusões is centered between the coordinates $09^{\circ} 13^{\prime} 22^{\prime \prime} \mathrm{S}$ and $43^{\circ} 29^{\prime} 23^{\prime \prime} \mathrm{W}$ and has an average elevation of approximately $700 \mathrm{~m}$. It is located in a transitional area between Caatinga and Cerrado with a predominance of arboreal and shrubby vegetation cover with the presence of semi-deciduous forests in some areas, within the geographic domain of the Atlantic Forest (Gonçalves, 2003).

Serra da Capivara National Park, on the other hand, is centered between the coordinates $08^{\circ} 41^{\prime} 42^{\prime \prime} \mathrm{S}$ and $42^{\circ} 35^{\prime} 10^{\prime \prime} \mathrm{W}$ and has an average elevation of approximately $500 \mathrm{~m}$. It has a relief with plateaus and valleys with differences of up to 250 meters. In the high plateau areas, the phytophysiognomy of dense arboreal Caatinga predominates, while in the valleys where humidity is highest, the phytophysiognomy is arboreal Caatinga, with open understory (Barros, et al., 2012).

The specimens were processed at the Laboratory of Ant Systematics and Biology of the Federal University of Paraná, Curitiba, Brazil. Identification to genus was accomplished with the help of the Guide for Ant Genera of Brazil (Baccaro et al., 2015) and for species we used the bibliographies recommended for each genus in this same Guide (Albuquerque \& Brandão, 2004; Cuezzo, 2000; Gonçalves, 1961; Jesovnik \& Schultz, 2017; Kempf, 1951, 1973; Kugler, 1994; LaPolla \& Fisher, 2005; Longino, 2003; Ortiz-Sepulveda et al., 2019; Schmidt \& Shattuck, 2014; Watkins, 1976). Vouchers were deposited in the Padre Jesus Santiago Moure Entomological Collection of the Universidade Federal do Paraná (DZUP), Curitiba, Brazil.

\section{RESULTS AND DISCUSSION}

A total of 152 ant species/morphospecies were recorded in the state of Piauí in 52 genera and nine subfamilies distributed in 24 locations (Table 1). A total of 96 species were namely identified (63\%) and 56 remained as morphospecies due to the lack of taxonomic resolution for their genera. The most diverse subfamilies were Myrmicinae, with 94 species, and Formicinae, with 21 species, represented by 25 and five genera, respectively. Among the genera, Pheidole had the highest number of species, 25, followed by Solenopsis, with 16 species, and Camponotus with 13 species. Considering the ant genera listed, 31 represent new records for the state. Regarding the species, 58 are new records, all of which are collected in Parque Nacional da Serra da Capivara and Parque Nacional da Serra das Confusões. Eight species represent new records for the Northeast Region of the country: Camponotus mus Roger, 1863, Hylomyrma blandiens Kempf, 1961, Pheidole cardinalis Wilson, 2003, Pheidole fracticeps Wilson, 2003, Pheidole geraesensis Santschi,
1929, Pheidole microps Wilson, 2003, Pheidole nubila Emery, 1906, and Strumigenys hindenburgi Forel, 1915. Additionally, there is a new record for Brazil, represented by the species Pheidole microps Wilson, 2003.

The diversity pattern found among the recorded taxa was somewhat expected as the two subfamilies and the most diverse genera in this paper are extremely rich and widely distributed in the Neotropical region (Ward et al., 2015). Myrmicinae can be considered the most successful group among all subfamilies of Formicidae, comprising almost $50 \%$ of the diversity of Formicidae (Ward et al., 2015; Bolton, 2019). Their dominance can be explained by the broad feeding and reproductive strategies (Agosti et al., 2000; Hamidi et al., 2017). Thus, the results obtained for this subfamily are within the expectations of the literature, since approximately $62 \%$ of the species registered in the state of Piauí belong to this group.

From the eight new ant species firstly recorded for the Northeast Region of Brazil, seven belong to megadiverse genera, including Pheidole, Camponotus, and Strumigenys. This highlights the importance of specific-level identification for an ant inventories, since these new records are both an artifact of the lack of expertise to identify these genera and the lack of data collection in Piauí state. In fact, different ant collections in Brazil probably hold unidentified specimens of Pheidole, Camponotus and similar genera that could be new records in species lists and surveys.

Two exotic species, Monomorium pharaonis (Linnaeus, 1758) and Paratrechina longicornis (Latreille, 1802), were recorded. These species had already been recorded for neighboring states (AntMaps, 2019; Prado et al., 2019). Monomorium pharaonis is considered a species of medical importance in many parts of the world, including Brazil, specifically in hospitals, where it is a potential carrier of pathogens (Wetterer, 2010). Paratrechina longicornis is considered an urban and agricultural pest in most of the tropics and subtropics of the world for infesting buildings and facilitating the multiplication of populations of Hemiptera that feed on plant phloem (Wetterer, 2008).

We recognize at least 11 new ant species (Table 2), of which one belongs to the genus Mycetophylax, one to Mycocepurus and nine to Pheidole. This demonstrates the great potential of this region to reveal taxonomic novelties, as predicted by Guénard et al. (2012), even though these authors referred to potential new genera.

Regarding the relative contribution of each data source (literature and expeditions) to compose the final list of species in Piauí, literature contributed $25 \%$ of the registered species (38 species), while the collecting expeditions were responsible for $75 \%$ of the species (114 species), 71 collected in Serra da Capivara and 101 in Serra das Confusões. It is noteworthy that all 58 new species records for the state come from these collecting expeditions. From the species collected specifically in the expeditions, 79 were sampled with pitfall traps in the soil, 21 were manually collected, and 27 were exclusively found in leaf-litter samples submitted to the Winkler extractor. This highlights the importance of collecting expeditions 
Table 2. Ant species recorded for the state of Piauí, Brazil. Numbers in the second column refer to the sources from which the occurrence information was obtained for each species, presented in the specific reference list below and in Table 1. Genera and species indicated with an asterisk $\left(^{*}\right)$ represent new records for the state of Piauí, two asterisks $\left({ }^{* *}\right)$ represent new records for the Northeast Region of Brazil and three asterisks ${ }^{* * *}$ ) represent new records for Brazil. Species indicated with a dagger ( $\dagger$ ) were recorded exclusively within the domain of the Atlantic Forest in the state, while all the other species were present only in savanna environments (Caatinga and/or Cerrado).

\begin{tabular}{|c|c|c|}
\hline Taxon & Source & $\begin{array}{l}\text { Sampling methods fo } \\
\text { sources } 11 \text { and } 12\end{array}$ \\
\hline \multicolumn{3}{|l|}{ Amblyoponinae } \\
\hline \multicolumn{3}{|l|}{ Prionopelta Mayr, $1866^{*}$} \\
\hline Prionopelta punctulata Mayr, $1866^{*}$ & $11 ; 12$ & Epigeic pitfall traps \\
\hline \multicolumn{3}{|l|}{ Dolichoderinae } \\
\hline \multicolumn{3}{|l|}{ Azteca Forel, 1878} \\
\hline Azteca sp. 1 & 12 & Hand collection \\
\hline Azteca sp. 2 & 11 & Hand collection \\
\hline \multicolumn{3}{|l|}{ Dorymyrmex Mayr, 1866} \\
\hline Dorymyrmex goeldii Forel, 1904 & 9 & \\
\hline Dorymyrmex sp. 1 aff. pyramicus & $11 ; 12$ & Epigeic pitfall traps \\
\hline Dorymyrmex sp. 2 & $11 ; 12$ & Epigeic pitfall traps \\
\hline Dorymyrmex sp. 3 & 12 & Epigeic pitfall traps \\
\hline Dorymyrmex sp. 4 & 11 & Epigeic pitfall traps \\
\hline \multicolumn{3}{|l|}{ Forelius Emery, 1888} \\
\hline Forelius brasiliensis (Forel, 1908)* & $11 ; 12$ & Epigeic pitfall traps \\
\hline Forelius pusillus Santschi, 1922 & 8 & \\
\hline Forelius sp. 1 & $11 ; 12$ & Epigeic pitfall traps \\
\hline \multicolumn{3}{|l|}{ Gracilidris Wild \& Cuezzo, 2006} \\
\hline Gracilidris pombero Wild \& Cuezzo, 2006 & 18 & \\
\hline \multicolumn{3}{|l|}{ Linepithema Mayr, 1866* } \\
\hline Linepithema neotropicum Wild, 2007* & 12 & Epigeic pitfall traps \\
\hline \multicolumn{3}{|l|}{ Tapinoma Foerster, 1850* } \\
\hline Tapinoma melanocephalum (Fabricius, 1793)* & 12 & Hand collection \\
\hline Tapinoma sp. 1 & 12 & Epigeic pitfall traps \\
\hline \multicolumn{3}{|l|}{ Dorylinae } \\
\hline \multicolumn{3}{|l|}{ Acanthostichus Mayr, 1887* } \\
\hline Acanthostichus sp. 1 aff. brevicornis & 11 & Epigeic pitfall traps \\
\hline \multicolumn{3}{|l|}{ Eciton Latreille, 1804* } \\
\hline Eciton dulcium Forel, 1912* & 11 & Epigeic pitfall traps \\
\hline \multicolumn{3}{|l|}{ Labidus Jurine, $1807^{*}$} \\
\hline Labidus coecus (Latreille, 1802)* & 12 & Epigeic pitfall traps \\
\hline \multicolumn{3}{|l|}{ Neivamyrmex Borgmeier, 1940} \\
\hline Neivamyrmex diana (Forel, 1912)* & 11 & Epigeic pitfall traps \\
\hline Neivamyrmex minensis (Borgmeier, 1928)* & 12 & Epigeic pitfall traps \\
\hline Neivamyrmex pertii (Shuckard, 1840) & $5 ; 16$ & \\
\hline \multicolumn{3}{|l|}{ Ectatomminae } \\
\hline \multicolumn{3}{|l|}{ Ectatomma Smith, 1858} \\
\hline Ectatomma muticum Mayr, 1870 & $6 ; 11 ; 12 ; 19 ; 22$ & Epigeic pitfall traps \\
\hline \multicolumn{3}{|l|}{ Gnamptogenys Roger, 1863* } \\
\hline Gnamptogenys striatula Mayr, $1884^{*}$ & $11 ; 12$ & Epigeic pitfall traps \\
\hline Gnamptogenys sulcata (Smith, 1858) & 12 & Hand collection \\
\hline \multicolumn{3}{|l|}{ Formicinae } \\
\hline \multicolumn{3}{|l|}{ Acropyga Roger, $1862^{*}$} \\
\hline Acropyga goeldii Forel, $1893^{* \dagger}$ & 12 & Winkler extractor \\
\hline \multicolumn{3}{|l|}{ Brachymyrmex Mayr, 1868* } \\
\hline Brachymyrmex coactus Mayr, $1887^{* \dagger}$ & 12 & Winkler extractor \\
\hline Brachymyrmex patagonicus Mayr, $1868^{*}$ & $11 ; 12$ & Epigeic pitfall traps \\
\hline Brachymyrmex pictus Mayr, $1887^{* \dagger}$ & 12 & Winkler extractor \\
\hline Brachymyrmex sp. 1 aff. fiebrigi & 12 & Epigeic pitfall traps \\
\hline Brachymyrmex sp. 2 & 11 & Epigeic pitfall traps \\
\hline
\end{tabular}

\begin{tabular}{|c|c|c|}
\hline Taxon & Source & $\begin{array}{l}\text { Sampling methods for } \\
\text { sources } 11 \text { and } 12\end{array}$ \\
\hline \multicolumn{3}{|l|}{ Camponotus Mayr, 1861} \\
\hline Camponotus arboreus (Smith, 1858)* & $11 ; 12$ & Hand collection \\
\hline Camponotus blandus (Smith, 1858)* & $11 ; 12$ & \\
\hline Camponotus cingulatus Mayr, $1862^{*}$ & 11 & Epigeic pitfall traps \\
\hline Camponotus crassus Mayr, 1862* & $11 ; 12$ & Epigeic pitfall traps \\
\hline Camponotus melanoticus Emery, 1894* & $11 ; 12$ & Epigeic pitfall traps \\
\hline Camponotus mus Roger, $1863^{* *}$ & 12 & Epigeic pitfall traps \\
\hline Camponotus renggeri Emery, 1894 & $19 ; 22$ & \\
\hline Camponotus substitutus Forel, 1899* & $11 ; 12$ & Hand collection \\
\hline Camponotus vittatus Forel, 1904* & $11 ; 12$ & Epigeic pitfall traps \\
\hline Camponotus sp. 1 & $11 ; 12$ & Epigeic pitfall traps \\
\hline Camponotus sp. 2 & $11 ; 12$ & Epigeic pitfall traps \\
\hline Camponotus sp. 3 & 11 & Epigeic pitfall traps \\
\hline Camponotus sp. 4 & 12 & Hand collection \\
\hline \multicolumn{3}{|l|}{ Nylanderia Emery, 1906* } \\
\hline Nylanderia sp. $1^{\dagger}$ & 12 & Winkler extractor \\
\hline \multicolumn{3}{|l|}{ Paratrechina Motschoulsky, 1863* } \\
\hline Paratrechina longicornis (Latreille, 1802)* & 12 & Hand collection \\
\hline
\end{tabular}

\section{Heteroponerinae}

Acanthoponera Mayr, 1862*

Acanthoponera mucronata (Roger, 1860)*

Epigeic pitfall traps

\section{Myrmicinae}

Acromyrmex Mayr, 1865

Acromyrmex landolti (Forel, 1885)

Acromyrmex rugosus (Smith, 1858)

$14 ; 16$

Apterostigma Mayr, 1865*

Apterostigma gr. pilosum sp. $1^{\dagger}$

Epigeic pitfall traps

\section{Atta Fabricius, 1804}

Atta laevigata (Smith, 1858)

Atta opaciceps Borgmeier, 1939

Atta sexdens (Linnaeus, 1758)

Epigeic pitfall traps

Blepharidatta Wheeler, 1915

Blepharidatta conops Kempf, 1967

Carebara Westwood, 1840*

Carebara gr. lignata sp. $1^{\dagger}$

Carebara brevipilosa Fernández, 2004*

\section{Cephalotes Latreille, 1802}

Cephalotes atratus (Linnaeus, 1758)

Cephalotes betoi De Andrade, 1999

Cephalotes clypeatus (Fabricius, 1804)

Cephalotes cordatus (Smith, 1853)

Cephalotes fiebrigi (Forel, 1906)

Cephalotes minutus (Fabricius, 1804)

Cephalotes pavonii (Latreille, 1809)*

Cephalotes persimilis De Andrade, 1999

Cephalotes pinelii (Guérin-Méneville, 1844)

Cephalotes pusillus (Klug, 1824)

12

\section{6}

16

$11 ; 16$

$11 ; 12 ; 7 \quad$ Epigeic pitfall traps

12 Winkler extractor

11 Epigeic pitfall traps

10

10; $19 ; 11,12 ; 22 \quad$ Hand collection

10; $12 ; 19 ; 22 \quad$ Hand collection

10

10

$10 ; 19 ; 22$

$11 ; 12 \quad$ Epigeic pitfall traps

10; $12 ; 19 ; 22 \quad$ Hand collection

10

Crematogaster Lund, 1831*

Crematogaster crinosa Mayr, 1862*

Crematogaster pygmaea Forel, $1904^{*}$ 


\begin{tabular}{l} 
Taxon \\
\hline Crematogaster sp. 1 aff. obscurata \\
Cyphomyrmex Mayr, 1862 \\
Cyphomyrmex rimosus (Spinola, 1851)* $^{*}$ \\
Cyphomyrmex transversus Emery, 1894 \\
Cyphomyrmex sp. $1^{\dagger}$ \\
Hylomyrma Forel, 1912* \\
Hylomyrma blandiens Kempf, 1961** \\
Kalathomyrmex Klingenberg \& Brandão, 2009 \\
Kalathomyrmex emeryi (Forel, 1907)
\end{tabular}

Monomorium Mayr, 1855*

Monomorium pharaonis (Linnaeus, 1758)*

Mycetarotes Emery, 1913*

Mycetarotes parallelus (Emery, 1906) ${ }^{*+}$

Mycetomoellerius Solomon et al., 2019*

Mycetomoellerius sp. $1^{\dagger}$

Mycetophylax Emery, 1913*

Mycetophylax sp. n.

Mycocepurus Forel, 1893*

Mycocepurus sp. $\mathrm{n}^{\dagger}$

Myrmicocrypta Smith, 1860*

Myrmicocrypta sp. 1

Oxyepoecus Santschi, 1926

Oxyepoecus kempfi Albuquerque \& Brandão, 2004

Oxyepoecus sp. 1 aff. vezenyii

Paratrachymyrmex Solomon et al., 2019*

Paratrachymyrmex bugnioni (Forel, 1912)*†

Pheidole Westwood, 1839*

Pheidole cardinalis Wilson, 2003**+

Pheidole exigua Mayr, 1884*

Pheidole fimbriata Roger, $1863^{*+}$

Pheidole fracticeps Wilson, 2003**

Pheidole geraesensis Santschi, $1929^{* *}$

Pheidole microps Wilson, 2003***+

Pheidole nubila Emery, 1906**

Pheidole obscurithorax Naves, $1985^{*}$

Pheidole radoszkowskii Mayr, 1884*

Pheidole subarmata Mayr, $1884^{* \dagger}$

Pheidole synarmata Wilson 2003*

Pheidole valens Wilson, 2003*

Pheidole cf. caribbaea

Pheidole cf. vallifica

Pheidole gr. aberrans sp. n.

Pheidole gr. diligens sp. $\mathrm{n}$.

Pheidole sp. 1 aff. rufipilis ${ }^{\dagger}$

Pheidole sp. 2 aff. radoszkowskii

Pheidole sp. n. 1 (aff. diligens)

Pheidole sp. n. 2 (aff. puttemansi)

Pheidole sp. n. 3 (aff. triconstricta)

Pheidole sp. n. 4

Pheidolesp. n. 5

Pheidolesp. n. 6

Pheidolesp. n. 7

Procryptocerus Emery, 1887

Procryptocerus hylaeus Kempf, 1951

Procryptocerus victoris Kempf, 1960

Rogeria Emery, 1894*

\begin{tabular}{|c|c|c|}
\hline Taxon & Source & $\begin{array}{l}\text { Sampling methods for } \\
\text { sources } 11 \text { and } 12\end{array}$ \\
\hline Rogeria curvipubens Emery, 1894*+ & 12 & Winkler extractor \\
\hline Rogeria foreli Emery, 1894*† & 12 & Winkler extractor \\
\hline Rogeria lirata Kugler, 1994* & $11 ; 12$ & Epigeic pitfall traps \\
\hline \multicolumn{3}{|l|}{ Sericomyrmex Mayr, 1865} \\
\hline Sericomyrmex mayri Forel, $1912^{\dagger}$ & $3 ; 12 ; 15$ & Winkler extractor \\
\hline Sericomyrmex scrobifer Forel, 1911 & $3 ; 15$ & \\
\hline \multicolumn{3}{|l|}{ Solenopsis Westwood, 1840} \\
\hline Solenopsis geminata (Fabricius, 1804) & $19 ; 22 ; 23$ & \\
\hline Solenopsis saevissima (Smith, 1855) & $19 ; 22$ & \\
\hline Solenopsis tridens Forel, 1911* & $11 ; 12$ & Epigeic pitfall traps \\
\hline Solenopsis sp. 1 & $11 ; 12$ & Epigeic pitfall traps \\
\hline Solenopsis sp. 2 & $11 ; 12$ & Epigeic pitfall traps \\
\hline Solenopsis sp. 3 & $11 ; 12$ & Epigeic pitfall traps \\
\hline Solenopsis sp. 4 & $11 ; 12$ & Epigeic pitfall traps \\
\hline Solenopsis sp. 5 & 11 & Epigeic pitfall traps \\
\hline Solenopsis sp. 6 & 11 & Epigeic pitfall traps \\
\hline Solenopsis sp. $7^{\dagger}$ & 12 & Winkler extractor \\
\hline Solenopsis sp. $8^{\dagger}$ & 12 & Winkler extractor \\
\hline Solenopsis sp. 9 & $11 ; 12$ & Hand collection \\
\hline Solenopsis sp. $10^{\dagger}$ & 12 & Winkler extractor \\
\hline Solenopsis sp. 11 & 11 & Epigeic pitfall traps \\
\hline Solenopsis sp. 12 & 11 & Epigeic pitfall traps \\
\hline Solenopsis sp. 13 & 11 & Epigeic pitfall traps \\
\hline \multicolumn{3}{|l|}{ Strumigenys Smith, 1860} \\
\hline Strumigenys crassicornis Mayr, $1887^{* \dagger}$ & 12 & Winkler extractor \\
\hline Strumigenys eggersi Emery, $1890^{*+}$ & 12 & Winkler extractor \\
\hline Strumigenys elongata Roger, 1863 & $4 ; 12$ & Winkler extractor \\
\hline Strumigenys hindenburgi Forel, $1915^{* *+}$ & 12 & Winkler extractor \\
\hline Strumigenys infidelis Santschi, 1919 & 4 & \\
\hline Strumigenys lilloana (Brown, 1950) & $3 ; 4 ; 19 ; 22$ & \\
\hline Strumigenys louisianae Roger, 1863 & $2 ; 6$ & \\
\hline Strumigenys sp. 1 aff. elongata & 12 & Winkler extractor \\
\hline Strumigenys sp. 2 aff. Iouisianae & 12 & Winkler extractor \\
\hline \multicolumn{3}{|l|}{ Wasmannia Forel 1893* } \\
\hline Wasmannia auropunctata (Roger, 1863) & 12 & $\begin{array}{l}\text { Epigeic pitfall traps, } \\
\text { Winkler extractor }\end{array}$ \\
\hline
\end{tabular}

Ponerinae

Anochetus Mayr, 1861*

Anochetus neglectus Emery, 1894*广

12

Centromyrmex Mayr, 1866

Centromyrmex brachycola (Roger, 1861)

Dinoponera Roger, 1861

Dinoponera quadriceps Kempf, 1971

Hypoponera Santschi, 1938*

Hypoponera sp. $1^{\dagger}$

$6 ; 11 ; 12 ; 19 ; 22 \quad$ Epigeic pitfall traps

Epigeic pitfall traps

Epigeic pitfall traps

Epigeic pitfall traps

Epigeic pitfall traps

Hypoponera sp. $2^{\dagger}$

Winkler extractor

Neoponera Emery, 1901

Neoponera bactronica (Fernandes et al., 2014)

Winkler extractor

Neoponera commutata (Roger, 1860)

Odontomachus Latreille, 1804*

Odontomachus bauri Emery, 1892*

Pseudoponera Emery, 1900*

Pseudoponera gilberti (Kempf, 1960)*

Pseudomyrmecinae

Pseudomyrmex Lund, 1831*

Pseudomyrmex gr. pallidus sp. 1

Pseudomyrmex tenuis (Fabricius, 1804)*†

Pseudomyrmex termitarius (Smith, 1855)*

\begin{tabular}{|c|c|}
\hline Source & $\begin{array}{l}\text { Sampling methods fo } \\
\text { sources } 11 \text { and } 12\end{array}$ \\
\hline 12 & Epigeic pitfall traps \\
\hline $11 ; 12$ & Epigeic pitfall traps \\
\hline $11 ; 12 ; 19 ; 22$ & $\begin{array}{l}\text { Epigeic pitfall traps, } \\
\text { Winkler extractor }\end{array}$ \\
\hline 12 & Winkler extractor \\
\hline 11 & Epigeic pitfall traps \\
\hline $12 ; 17 ; 19 ; 22$ & Hand collection \\
\hline 12 & Hand collection \\
\hline 12 & Hand collection \\
\hline 12 & Hand collection \\
\hline 12 & $\begin{array}{l}\text { Epigeic pitfall traps, } \\
\text { Winkler extractor }\end{array}$ \\
\hline 12 & Hand collection \\
\hline 11 & Epigeic pitfall traps \\
\hline $1 ; 22$ & \\
\hline $11 ; 12$ & Epigeic pitfall traps \\
\hline 12 & Winkler extractor \\
\hline 12 & Winkler extractor \\
\hline $11 ; 12$ & Epigeic pitfall traps \\
\hline 12 & Hand collection \\
\hline $11 ; 12$ & Epigeic pitfall traps \\
\hline $11 ; 12$ & Epigeic pitfall traps \\
\hline 12 & Epigeic pitfall traps \\
\hline $11 ; 12$ & Epigeic pitfall traps \\
\hline $11 ; 12$ & Epigeic pitfall traps \\
\hline 12 & Epigeic pitfall traps \\
\hline 12 & Winkler extractor \\
\hline 12 & Epigeic pitfall traps \\
\hline 11 & Epigeic pitfall traps \\
\hline 11 & Epigeic pitfall traps \\
\hline 11 & Epigeic pitfall traps \\
\hline 12 & Epigeic pitfall traps \\
\hline $11 ; 12$ & Epigeic pitfall traps \\
\hline 12 & Epigeic pitfall traps \\
\hline $11 ; 12$ & Epigeic pitfall traps \\
\hline $11 ; 12$ & Epigeic pitfall traps \\
\hline $11 ; 12$ & Epigeic pitfall traps \\
\hline 11 & Epigeic pitfall traps \\
\hline 11 & Epigeic pitfall traps \\
\hline $11 ; 12$ & Epigeic pitfall traps \\
\hline 11 & Epigeic pitfall traps \\
\hline 12 & Epigeic pitfall traps \\
\hline \multicolumn{2}{|l|}{$3 ; 20$} \\
\hline 3 & \\
\hline
\end{tabular}


to increase our knowledge of the ant fauna in subsampled areas of the Neotropics, especially when involving multiple collecting techniques.

Regarding the representativity of ants in the different biomes of Piauí, it is not possible to characterize species typical of Cerrado or Caatinga, since these species can be found in both ecosystems and have been classified as "savanna specialists" (Leal et al., 2017; Vasconcelos et al., 2017). As for the Atlantic Forest ants, they are represented in our dataset by the specimens obtained from leaf-litter samples exclusive of our collection efforts in Parque Nacional da Serra das Confusões (Table 2).

The list of species presented here considerably increases the number of species previously recorded in the state. From 48 records (AntMaps, 2019), the number of ant species for Piauí went to 152. Nevertheless, these numbers are constantly changing as taxonomic works are published frequently and this process leads to the documentation of new species (Ward, 2007), as well as the establishment of local research groups and field trips. Thus, the list of species presented here is likely to grow with future collecting and advances in ant studies.

\section{ACKNOWLEDGMENTS}

We are deeply indebted to Gabriela P. Camacho and Mila F.O. Martins for the support during fieldwork. Thanks to Alexandre Casadei Ferreira, Aline Machado Oliveira, Natalia Ladino, Thiago S.R. da Silva, and Weslly Franco for identifying our species of Pheidole, Cephalotes, Prionopelta, Strumigenys, and Gnamptogenys, respectively. We thank Dr. Christian Rabeling for confirming the new species belonging to the genus Mycocepurus. We are also grateful to three anonymous reviewers for the valuable comments on a previous version of this work. This study was funded by the Conselho Nacional de Desenvolvimento Científico e Tecnológico - CNPq (grants 1302462/2016-3 and $128319 / 2017-8$ to RMF and TJ, respectively), and the Partnerships for Enhanced Engagement in Research (PEER) Science Program (NAS/USAID - award number AID-OAA-A-11-00012 - project 3-188).

\section{REFERENCES}

Agosti, D.; Majer, J.D.; Alonso, L.E. \& Schultz, T.R. 2000. Ants: Standard methods for measuring and monitoring biodiversity. Washington, D.C., Smithsonian Institution Press. 304p.

Aguiar, T.J.A. \& Monteiro, M.S.L. 2005. Modelo agrícola e desenvolvimento sustentável: a ocupação do cerrado piauiense. Ambiente \& Sociedade, 8(2): 1-18.

Albuquerque, N.L. \& Brandão, C.R.F. 2004. A revision of Neotropical Solenopsidini ant genus Oxyepoecus Santschi, 1926 (Hymenoptera: Formicidae: Myrmicinae). 1. The Vezenyii species-group. Papéis Avulsos de Zoologia, 44: 55-80.

Antmaps, 2019. Available at: http://antmaps.org. Access in: 11/09/2019.

Baccaro, F.B.; Feitosa, R.M.; Fernandez, F.; Fernandes, I.0.; Izzo, T.J.; Souza, J.P. de \& Solar, R. 2015. Guia para os gêneros de formigas do Brasil. Manaus, Editora INPA. 388p.
Barros, J.S.; Ferreira, R.V.; Guidon, N. \& Pereira da Silva, A.J.C.L. 2012. Geoparque Serra da Capivara - PI: Proposta. In: Schobbenhaus, C.; Silva, C.R. (Org.). Geoparques do Brasil. Brasilia, Serviço Geológico Brasileiro, CPRM. p. 493-542.

Bolton, B. 2019. An online catalog of the ants of the world. Available at: http:// antcat.org. Access in: 06/09/2019.

Camargo, K.S. 2011. Composição e diversidade de "Poneromorfas" (Hymenoptera, Formicidae) em duas fitofisionomias de cerrado e padrões de distribuição de "Poneromorfas", Pseudomyrmecinae e Cephalotini (Myrmicinae) para o Brasil. (Tese de doutorado em ecologia). Universidade de Brasília, Brasília, D.F. 80p.

Castro, D.; Fernández, F.; Meneses, A.D.; Tocora, M.C.; Sanchez, S. \& PeñaVenegas, C.P. 2018. A preliminary checklist of soil ants (Hymenoptera: Formicidae) of Colombian Amazon. Biodiversity Data Journal, 6: e29278.

Choe, J. 2012. Secret Lives of Ants. Baltimore, Johns Hopkins University Press. 184 p. ilus.

Cuezzo, F. 2000. Revisión del género Forelius (Hymenoptera: Formicidae: Dolichoderinae). Sociobiology, 35: 197-275.

Demétrio, M.F.; Silvestre, R.; Souza, P.R. \& Aoki, C. 2017. Inventário da fauna de formigas (Hymenoptera, formicidae) no Mato Grosso do Sul, Brasil. Iheringia, série zoologia, 107: 1-12.

Fontes, L.S. \& Almeida Filho, A.J. 2002. Espécies de formigas cortadeiras do estado do Piauí, Brasil. Revista de Agricultura, Piracicaba, 77(2): 305-310.

Gonçalves, C.R. 1961. 0 gênero Acromyrmex no Brasil (Hym. Formicidae). Studia Entomologica, 4: 113-180.

Gonçalves, M.R. 2003. Plano de Manejo do Parque Nacional da Serra das Confusões - PI. Brasília, IBAMA. 230p.

Guénard, B.; Weiser, M.D. \& Dunn, R.R. 2012. Global models of ant diversity suggest regions where new discoveries are most likely are under disproportionate deforestation threat. Proceedings of the National Academy of Science of the United States of America, 109(19): 7368-7373.

Hamidi, R.; Biseau, J.C.; Bourguignon, T.; Segundo, G.B.M.; Fontenelle, M.T.M.B. \& Quinet, Y. 2017. Dispersal strategies in the highly polygynous ant Crematogaster (Orthocrema) pygmaea Forel (Formicidae: Myrmicinae). Plos One, 12(6): e0178813.

Jesovnik, A. \& Schultz, T.R. 2017. Revision of the fungus-farming ant genus Sericomyrmex Mayr (Hymenoptera, Formicidae, Myrmicinae). ZooKeys, 670: 1-109.

Kempf, W.W. 1951. A taxonomic study on the ant tribe Cephalotini (Hymenoptera: Formicidae). Revista de Entomologia, 22: 1-244.

Kempf, W.W. 1973. A revision of the Neotropical myrmicine ant genus Hylomyrma Forel (Hymenoptera: Formicidae). Studia Entomologica, 16: 225-260.

Kugler, C. 1994. A revision of the ant genus Rogeria with description of the sting apparatus (Hymenoptera: Formicidae). Journal of Hymenoptera Research, 3: 17-87.

Lacombe, A.L.M. 1969. Algumas considerações sobre os incentivos fiscais. Revista de Administração de Empresas, 9(4): 107-117.

Lemanceau, P. \& Blouin, M. 2018. Soil as a key component of the critical zone 6: Ecology. London, Wiley, ISTE. 196p.

LaPolla, J.S. \& Fisher, B.L. 2005. A remarkable new species of Acropyga (Hymenoptera: Formicidae) from Gabon, with a key to the Afrotropical species. Proceedings of the California Academy of Sciences, 56(4): 601-605.

Leal, I.; Ribeiro-Neto, J.D.; Arnan, X.; Oliveira A.F.M.; Arcoverde, G.B.; Feitosa, R.M.; Andersen, A.N. 2017. Ants of the Caatinga: diversity, biogeography, and functional responses to anthropogenic disturbance and climate change. In:Silva, J.M.C.; Leal, I.R.; Tabarelli, M. (Org.). Caatinga: the largest tropical dry forest region in south america. Berlim, Springer. p. 65-95.

Longino, J.T. 2003. The Crematogaster (Hymenoptera, Formicidae, Myrmicinae) of Costa Rica. Zootaxa, 151: 1-150. 
Machado, R.B.; Ramos Neto, M.B.; Pereira, P.G.P.; Caldas, E.F.; Gonçalves, D.A.; Santos, N.S.; Tabor, K. \& Steininger, M. 2004. Estimativa de perda da área do Cerrado brasileiro. Relatório técnico. Brasília, DF., Conservação Internacional. 71p.

Ministério do Meio Ambiente (MMA). 2018. Desmatamento no Cerrado em 2018. Available at: https://www.mma.gov.br/component/k2/ item/15309-desmatamento-no-bioma-cerrado-em-2018.html. Access in: 19/08/2019.

Ortiz-Sepulveda, C.M.; Bocxlaer, B.V.; Meneses, A.D. \& Fernández, F. 2019. Molecular and morphological recognition of species boundaries an the neglected ant genus Brachymyrmex (Hymenoptera: Formicidae): Toward a taxonomic revision. Organisms Diversity \& Evolution, 19: 447-542.

Prado, L.P.; Feitosa, R.M.; Triana, S.P.; Gutiérrez, J.A.; Rousseau, G.X., Silva, R.A.; Siqueira, G.M.; Santos, C.L.; Silva, F.V.; Silva, T.S.R.; Casadei-Ferreira, A.; Silva, R.R. \& Andrade-Silva, J. 2019. An overview of the ant fauna (Hymenoptera: Formicidae) of the state of Maranhão, Brazil. Papéis Avulsos de Zoologia, 59: e20195938.

Ribas, C.R.; Campos, R.B.F.; Schimidt, F.A. \& Solar, R.C.C. 2012. Ants as Indicators in Brazil: A review with suggestions to improve the use of ants in environmental monitoring programs. Psyche, 2012: 1-23.

Schmidt, C.A. \& Shattuck, S.0. 2014. The higher classification of the ant subfamily Ponerinae (Hymenoptera: Formicidae), with a review of Ponerinae ecology and behavior. Zootaxa, 3817(1): 1-242.

Silvestre, R.; Brandão, C.R.F. \& Silva, R.R. 2003. Grupos funcionales de hormigas: el caso de los gremios del Cerrado, Brasil. In: Fernández, F.
Introducción a las hormigas de la región neotropical. Bogotá, Instituto de Investigación de Recursos Biológicos Alexander von Humboldt. p. 101-136.

Vasconcelos, H.L.; Maravalhas, J.B.; Feitosa, R.M.; Pacheco, R.; Neves, K.C.; Andersen, A.N. 2017. Neotropical savanna ants show a reversed latitudinal gradient of species richness, with climatic drivers reflecting the forest origin of the fauna. Journal of Biogeography, 45(1):248-258.

Vicente, R.E.; Ferreira, A.C.; Santos, R.C.L. \& Prado, L.P. 2018. Ants (Hymenoptera: Formicidae) from an Amazonian fragmented landscape, Juara, Mato Grosso, Brazil, with new records of ant species. Papéis Avulsos de Zoologia, 58: e20185840. DOl

Ward, P.S. 2007. Phylogeny, classification, and species-level taxonomy of ants (Hymenoptera: Formicidae). Zootaxa, 1668: 549-563.

Ward, P.S.; Brady, S.G.; Fisher, B.L. \& Schultz, T.R. 2015. The evolution of Myrmicinae ants: phylogeny and biogeography of a hyperdiverse ant clade (Hymenoptera: Formicidae). Systematic Entomology, 40: 61-81.

Watkins, J.F. 1976. The identification and distribution of New World army ants (Dorylinae: Formicidae). Waco, Texas, Baylor University Press. 102p.

Wetterer, J.K. 2008. Worldwide spread of the longhorn crazy ant, Paratrechina longicornis (Hymenoptera: Formicidae). Myrmecological News, 11: 137-149.

Wetterer, J.K. 2010. Worldwide spread of the pharaoh ant, Monomorium pharaonis (Hymenoptera: Formicidae). Myrmecological News, 13: 115-129. 


\section{REFERENCES AND SOURCES FOR THE LOCALITIES AND SPECIES RECORDS IN TABLES 1 AND 2.}

(1) Albuquerque N.L. \& Brandão, C.R.F. 2004. A revision of the Neotropical Solenopsidini ant genus Oxyepoecus Santschi, 1926 (Hymenoptera: Formicidae: Myrmicinae). 1. The Vezenyii species-group. Papéis Avulsos de Zoologia, 44(4): 55-80.

(2) Almeida Filho A.J. 1984. Notas sobre Strumigenys louisianae (Hymenoptera, Formicidae) e sua ocorrência no Nordeste do Brasil. Quid Teresina, 5: $133-139$.

(3) AntWeb, 2019. Available at: http://www.antweb.org. Access in: 18/07/2019.

(4) Bolton, B. 2000. The Ant Tribe Dacetini. Memoirs of the American Entomological Institute, Universidade de Wisconsin, Madison, United States. 1028p.

(5) Borgmeier T. 1953. Vorarbeiten zu einer Revision der Neotropischen Wanderameisen. Studia Entomologica, 2: 1-51.

(6) Brandão, C.R.F. 1991. Adendos ao catálogo abreviado das formigas da região neotropical (Hymenoptera: Formicidae). Revista Brasileira de Entomologia, 35(2): 319-412.

(7) Brandão C.R.F.; Feitosa, R.M. \& Diniz, J.L.M. 2015. Taxonomic revision of the Neotropical Myrmicinae ant genus Blepharidatta Wheeler. Zootaxa, 4012 (1): $33-56$.

(8) Cuezzo F. 2000. Revisión del género Forelius (Hymenoptera: Formicidae: Dolichoderinae). Sociobiology, 35(2): 197-275.

(9) Cuezzo F. \& Guerrero, R.J. 2011. The ant genus Dorymyrmex Mayr (Hymenoptera: Formicidae: Dolichoderinae) in Colombia. Psyche, 2011: 1-24.

(10) De Andrade, M.L. \& Baroni Urbani, C. 1999. Diversity and Adaptation in the ant genus Cephalotes, past and present. Stuttgarter Beitrage zur Naturkunde Serie B, 271: 1-893.

(11) DZUP - Coleção Entomológica Padre Jesus Santiago Moure, Universidade Federal do Paraná, Brasil. Expedição ao Parque Nacional da Serra da Capivara.

(12) DZUP - Coleção Entomológica Padre Jesus Santiago Moure, Universidade Federal do Paraná, Brasil. Expedição ao Parque Nacional da Serra das Confusões.

(13) Fernandes I.0.; de Oliveira, M.L. \& Delabie J.H.C. 2014. Description of two new species in the Neotropical Pachycondyla foetida complex (Hymenoptera: Formicidae: Ponerinae) and taxonomic notes on the genus. Myrmecological News, 19: 133-163.

(14) Gonçalves C.R. 1961. 0 gênero Acromyrmex no Brasil (Hymenoptera: Formicidae). Studia Entomologica, 4: 113-180.

(15) Jesovnik A. \& Schultz T.R. 2017. Revision of the fungus-farming ant genus Sericomyrmex Mayr (Hymenoptera, Formicidae, Myrmicinae). ZooKeys, 670: 1-109.

(16) Kempf, W.W. 1972. Catálogo abreviado das formigas da região Neotropical (Hymenoptera: Formicidae). Studia Entomologica, 15: 1-4.

(17) Klingenberg C.\& Brandão, C.R.F. 2009. Revision of the fungus-growing ant genera Mycetophylax Emery and Paramycetophylax Kusnezov rev. stat., and description of Kalathomyrmex n. gen. (Formicidae: Myrmicinae: Attini). Zootaxa, 2052: 1-31.

(18) Koch, E.B.A.; Correia, J.P.S.O.; Menezes, R.S.T.; Silvestrini, R.A.; Delabie, J.H.C. \& Vasconcelos, H.L. 2018. New Records and Potential Distribution of the Ant Gracilidris pombero Wild \& Cuezzo (Hymenoptera: Formicidae). Sociobiology, 65(3): 375-382.

(19) Leal, I.R.; Ribeiro-Neto, J.D.; Arnan, X.; Oliveira, F.M.P.; Arcoverde, G.B.; Feitosa, R.M. \& Andersen, A.N. 2017. Ants of the Caatinga: diversity, biogeography, and functional responses to anthropogenic disturbance and climate change. In: Cardoso da Silva J.M.; Leal, I.R. \& Tabarelli, M., Caatinga. Springer, Cham, 65-96.

(20) Longino, J.T. \& Snelling, R.R. 2002. A taxonomic revision of the Procryptocerus (Hymenoptera: Formicidae) of Central America. Contributions in Science, 495: 1-30.

(21) MacKay, W.P. \& MacKay, E.E. 2010. The systematics and biology of the New World ants of the genus Pachycondyla (Hymenoptera: Formicidae). Edwin Mellen Press Lewiston, NY. 642p.

(22) Ulysséa, M.A. \& Brandão C.R.F. 2013. Ant species (Hymenoptera, Formicidae) from the seasonally dry tropical forest of northeastern Brazil: a compilation from field surveys in Bahia and literature records. Revista Brasileira de Entomologia, 57(2): 217-224.

(23) Wauters N.; Dekoninck, W. \& Fournier, D. 2018. Introduction history and genetic diversity of the invasive ant Solenopsis geminata in the Galapagos Islands. Biological Invasions, 20:3207-3226. 